\title{
A SORRY TALE: NATIVES, SETTLERS, AND THE SALMON OF LAKE ONTARIO,

\author{
$1780-1900^{*}$
}

\author{
KARIM M. TIRO \\ Xavier University
}

\begin{abstract}
A B ST RACT. Through the end of the eighteenth century, Lake Ontario had a large population of Atlantic salmon. However, the salmon population declined precipitously in the first half of the nineteenth century, and the fish had disappeared completely by I 900 . This article analyses the responses of both Natives and settlers to initial salmon abundance and subsequent diminution. Although the extirpation of the lake's salmon is generally attributed to the construction of dams, this article identifies earlier and broader causes of salmon decline. In both Canada and the United States, commercial fishing captured unprecedented numbers of fish while agriculture and deforestation compromised salmon spawning habitat. While primary responsibility for the extirpation rests with the settlers, both Natives and Euro-Americans treated the fish as a commodity. As the salmon dwindled, sportsmen's groups came to the fore in setting fisheries policy. Sportsmen supported enhanced conservation measures but based their strategy on unrealistic methods for reviving the fish population through pisciculture.
\end{abstract}

In 1792, the exiled scholar Francis Adrian van der Kemp wrote of the Lake Ontario watershed, 'Never did I see yet a country, where all kind of fish was so abundant and good' (Figure 1). As a Dutchman, he spoke with a certain authority on the subject. He took particular note of the abundance of the king of fish, claiming that an 'Oneida Indian took with his spear, forty-five salmon in one hour'. 'Van der Kemp went on to make a home for himself in this fishy

Department of History, Xavier University, I Academic Mall, I 520 Herald Avenue, Cincinnati, Ohio 45207 USA

* The author wishes to acknowledge the assistance of Tricia Barbagallo, Robert A. Daniels, Todd E. A. Larson, and John Reiger. Research was supported by Hackman and Cunningham Residencies from the New York State Archives and the New York State Library respectively. Earlier versions of this article were presented at the 2012 Annual Meeting of the Organization of American Historians and as the 2012 Wendell Tripp Lecture to the Conference on New York State History.

1 Francis Adrian van der Kemp, 'Extracts from the Vanderkemp letters from the Hudson to Lake Ontario in 1792', Publications of the Buffalo Historical Society, 2 (1880), p. 67; Harry F. Jackson, Scholar in the wilderness: Francis Adrian Van der Kemp (Syracuse, NY, 1963), p. 88. 


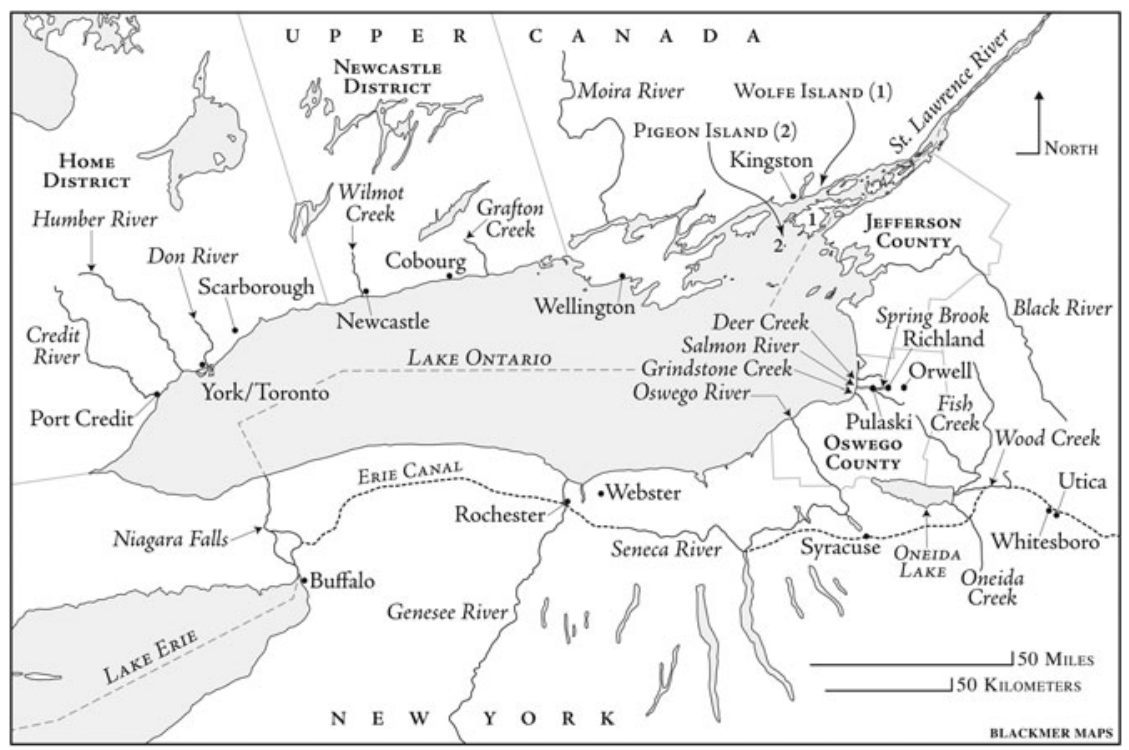

Fig. 1. Map of Lake Ontario region indicating places named in the text. Map by Kate Blackmer.

utopia, and he prospered. However, the Atlantic salmon (Salmo salar) did not. In 1817 , Van der Kemp penned a friendly missive to New York governor DeWitt Clinton. A mere quarter century after his initial observations, he now found occasion to rue the diminution of salmon. He believed the problem was 'fishing in the improper season', and he hinted at the grand economic opportunities lost by the failure to recognize salmon's true commodity value. 'The Salmon wellsmoaked', Van der Kemp told Clinton, 'would become a gold-mine for that part of the state.' ${ }^{2}$ As the decades passed, more people-Native and European, in Upper Canada and New York - came to share Van der Kemp's opinion that something had to be done to save the Atlantic salmon of Lake Ontario. Rituals were offered and laws were passed, but to little effect. Despite their documented abundance in 1800 , these fish were mostly gone by mid-century. Salmon populations collapsed entirely by 1880 , despite a robust effort to stock the lake's tributaries. Reported salmon sightings or captures grew increasingly rare until the last one in 1898.3

${ }^{2}$ Van der Kemp to DeWitt Clinton, 25 Sept. 1817, DeWitt Clinton papers, Columbia University Library, New York, NY; Vivian C. Hopkins, 'The governor and the Western recluse: DeWitt Clinton and Francis Adrian Van der Kemp', Proceedings of the American Philosophical Society, 105 (1961), p. 323.

3 A. G. Huntsman, 'Why did Ontario salmon disappear?', Transactions of the Royal Society of Canada, $3^{8}$ (1944), pp. $83-7$. 
Why did the salmon disappear so quickly? Many theories were aired and many fingers pointed: blame was cast upon the wastes produced by mills, factories, and farms; deforestation; overfishing; and dams that obstructed the salmon's passage to the spawning grounds. As the last fish disappeared, most people settled on the latter explanation. However, blaming the dam was attractive because it ascribed culpability narrowly and obscured other, earlier, and more broadly social, causes. The truth was that the Atlantic salmon's extirpation in Lake Ontario involved not just mill-owners, but farmers, fishermen, merchants, and consumers. 4 Identifying a principal cause obscures the powerful synergistic interaction of multiple factors. Although we idealize the agricultural landscape of North America before the Second Industrial Revolution, we underestimate the environmental impact of its technology and land use practices. 5 The story of Lake Ontario salmon makes this impact visible. Historian Joseph Taylor III's observation that the story of salmon decline in the Pacific Northwest was both longer and more complex than we realize certainly applies to Lake Ontario. However, unlike the salmon of the Pacific Northwest (or the Atlantic cod, to take another celebrated example), the extirpation of Lake Ontario salmon was achieved with a still-lower level of technology and capital. It was set in motion by the commodification of the fish, but had little to do with canning or refrigeration, hydroelectric dams, or industrial or municipal pollution. ${ }^{6}$

Salmon are a 'charismatic' species: they attract disproportionate attention and sympathy. As a result, they illuminate conservationist sentiment brightly. Scholars of the historical environment have nevertheless neglected Lake Ontario's salmon population. Early US environmental historians have largely

4 Dwight A. Webster, 'Early history of the Atlantic salmon in New York', New York Fish and Game Journal, 29 (1982), pp. 26-44; Robert J. Behnke, Trout and salmon of North America (New York, NY, 2001), pp. 241-52; Huntsman, 'Why did Ontario salmon disappear?', pp. 83-9o; W. Sherwood Fox, 'The literature of salmo salar in Lake Ontario', Transactions of the Royal Society of Canada, 24 (1930), pp. 45-55; Stanford H. Smith, Early changes in the fish community of Lake Ontario (Ann Arbor, MI, 1995), pp. 177-215; P. G. Sly, 'The effects of land use and cultural development on the Lake Ontario ecosystem since 1750', Hydrobiologia, 213 (1991), pp. 1-75; John W. Parsons, History of salmon in the Great Lakes, I850-1970 (Washington, DC, 1973), pp. 6-23; W.J. Christie, A review of the changes in the fish species composition of Lake Ontario (Ann Arbor, MI, 1973), pp. 30-3.

5 Donna L. Parrish, Robert J. Behnke, Stephen R. Gephard, Stephen D. McCormick, and Gordon H. Reeves, 'Why aren't there more Atlantic Salmon (Salmo Salar)?', Canadian Journal of Fisheries and Aquatic Science, 55, suppl. 1 (1998), pp. 281-7; Daniel Vickers, 'The dammed shad: would the river fisheries of New England have survived in the absence of industrialization?', William and Mary Quarterly, 61 (2004), pp. 685-712; Richard C. Hoffman, 'Economic development and aquatic ecosystems in medieval Europe', American Historical Review, 101 (1996), pp. 631-69.

${ }^{6}$ Joseph E. Taylor III, Making salmon: an environmental history of the Northwest fisheries crisis (Seattle, WA, 1999); Mark Kurlansky, Cod: a biography of the fish that changed the world (New York, NY, 1998); Nicolaas Mink, Salmon: a global history (New York, NY, 2013), p. 5o; Arthur F. McEvoy, The fisherman's problem: ecology and law in the California fisheries, I850-I980 (New York, NY, 1986). 
limited their interest to New England. Although the salmon are duly acknowledged as part of the early settlement history of Ontario's littoral towns, geographer Brian Osborne has observed, 'Most researchers of Ontario's settlement history have stood with their backs to the Great Lakes.' 7 Canadian fisheries historians tend to favour the Maritime provinces, where fish became an economic mainstay. Finally, historians of the Great Lakes and its fisheries have traditionally given Lake Ontario short shrift as a result of its eastern location and relatively small size. The notable exception to this has been historian Margaret Beattie Bogue. Bogue noted that, although Atlantic salmon were not present in the other lakes due to the height of Niagara Falls, the extirpation of Lake Ontario's salmon 'foreshadowed the general decline of Great Lakes commercial fishing'. ${ }^{8}$ It also prefigured the rapid diminution of other abundant creatures of land and air. During these years, humans commodified bison and passenger pigeons while simultaneously compromising their habitats, with devastating results. This article treats Lake Ontario as central to the environmental history of the North American continent, rather than a body of water peripheral to two nations. 9

The salmon that grace the lines of anglers in Lake Ontario today are Pacific transplants. The fish that Van der Kemp saw had originated from the general North Atlantic stock. Most, if not all, of these fish had abandoned the habit of migrating to salt water before returning to their natal streams to spawn. Lake Ontario's expanse and depth permitted them to dispense with that journey. Lake Ontario's Atlantic salmon spawned in the gravel beds of cool, rapid-flowing streams. After one to three years (but sometimes more), they went out to the open lake, mingling with salmon from other tributaries for two or more years before returning to spawn. Unlike their Pacific counterparts, some Atlantic salmon can spawn more than once in their lifetimes. Their reported size was equivalent to ocean-going Atlantic salmon: between 15 to 20 pounds, with the largest approximately twice that. In describing Lake Ontario salmon's size, or the colour or taste of their flesh, most observers downplayed any differences between the lake salmon and those found nearer the ocean. ${ }^{10}$ Salmon returned to the spawning grounds in large numbers in the late spring. Smaller numbers arrived thereafter until the large autumn run

7 Brian S. Osborne, 'Organizing the lake fisheries: landscapes and waterscapes', Historic Kingston, 38 (1990), p. 81.

8 Margaret Beattie Bogue, Fishing the Great Lakes: an environmental history, $1783^{-1933}$ ((Madison, WI, 2000), pp. 19-27, at p. 27.

9 Andrew C. Isenberg, The destruction of the bison: an environmental history, 1750-1920 (New York, NY, 200o); Joel Greenberg, A feathered river across the sky: the passenger pigeon's flight to extinction (New York, NY, 2014); James Feldman and Lynne Heasley, 'Recentering North American environmental history: pedagogy and scholarship in the Great Lakes', Environmental History, 12 (2007), pp. 951-8.

${ }^{10}$ Robert Gourlay, A statistical account of Upper Canada (London, 1822), 176; George Henry, The emigrant's guide, or Canada as it is (Québec, QC, 1832), pp. 266-7; Thomas William Magrath, Authentic letters from Upper Canada (Toronto, ON, 1953), pp. 181-2; Edith Firth, ed., The town of York, I793-1815 (Toronto, ON, 1962), 237. 
took place in October-November. Like all salmon, they had a strong homing instinct, returning to their stream of origin and reproducing with the same population. As a result, variations existed among the salmon of different watercourses. As one nineteenth-century observer noted, 'An experienced fisherman could readily tell from which stream a fish was caught, though they are but four miles apart. In Deer Creek the fish were long and slim, in Grindstone short and chubby, and in Salmon River large and heavy.' ${ }^{11}$

It is impossible to establish the size of this salmon population with precision, but Van der Kemp's expression of wonder at the plenitude of salmon in 1792 was consistent with more than a century and a half of European writings about Lake Ontario. Earlier European visitors, such as the Jesuit missionaries, had made similar observations. Of course, as historians like W. Jeffrey Bolster have noted, European observers of America defined abundance in relation to the depleted waters of their home continent. Moreover, the numbers they saw did not necessarily represent a stable baseline population. ${ }^{12}$ Nevertheless, the variety of witnesses who attested to the presence of a very large salmon population in Lake Ontario establishes the abundance of salmon in the late 1700 . So too does the ubiquity of salmon in the diets of Natives and early settlers. ${ }^{13}$

Salmon are usually associated with Native peoples of the Pacific coast, but the documentary record makes it clear that salmon were very important around Lake Ontario as well. Both Algonquian and Iroquoian peoples harvested the salmon in a manner that was intensive yet sustainable. Major Robert Rogers, observing Native salmon fishing at the Moira River in $176_{5}$, wrote, 'Their method of catching the fish is very extraordinary. One person holds a lighted pine-torch, while a second strikes the fish with a spear.' Myriad similar descriptions with varying levels of detail exist (Figure 2). ${ }^{14}$

${ }^{11}$ George Brown Goode, 'The salmon - Salmo salar', in The fisheries and fishery industries of the United States, section I: natural history of useful aquatic animals (Washington, DC, 1884), p. 474.

${ }_{12}$ W. Jeffrey Bolster, The mortal sea: fishing the Atlantic in the age of sail (Cambridge, MA, 201 2), pp. 40-8; Yolanda F. Wiersma and John Sandlos, 'Once there were so many: animals as ecological baselines', Environmental History, 16 (2011), pp. 400-40.

13 Anthropologist Catherine Carlson has argued that the abundance of Atlantic salmon was largely a figment of Europeans' imaginations. However, Carlson's analysis rests on a partial review of the archaeological and documentary evidence. 'The (in)significance of Atlantic salmon in New England', in Peter Benes, ed., New England's creatures, I4oo-I9oo (Boston, MA, 1995), pp. 13-23; for a contrary view, see Brian S. Robinson, George L. Jacobson, Martin G. Yates, Arthur E. Spiess, and Ellen R. Cowie, 'Atlantic salmon, archaeology and climate change in New England', Journal of Archaeological Science, 36 (2009), pp. 2184-91; Stephen F. Jane, Keith H. Nislow, and Andrew R. Whiteley, 'The use (and misuse) of archaeological salmon data to infer historical abundance in North America with a focus on New England', Reviews in Fish Biology and Fisheries, 24 (2014), pp. 943-54.

${ }^{14}$ Michael Recht, 'The role of fishing in the Iroquois economy, 16oo-1792', New York History, $7^{6}$ (1995), pp. 5-3o; Franklin B. Hough, ed., Journal of Major Robert Rogers (Albany, 


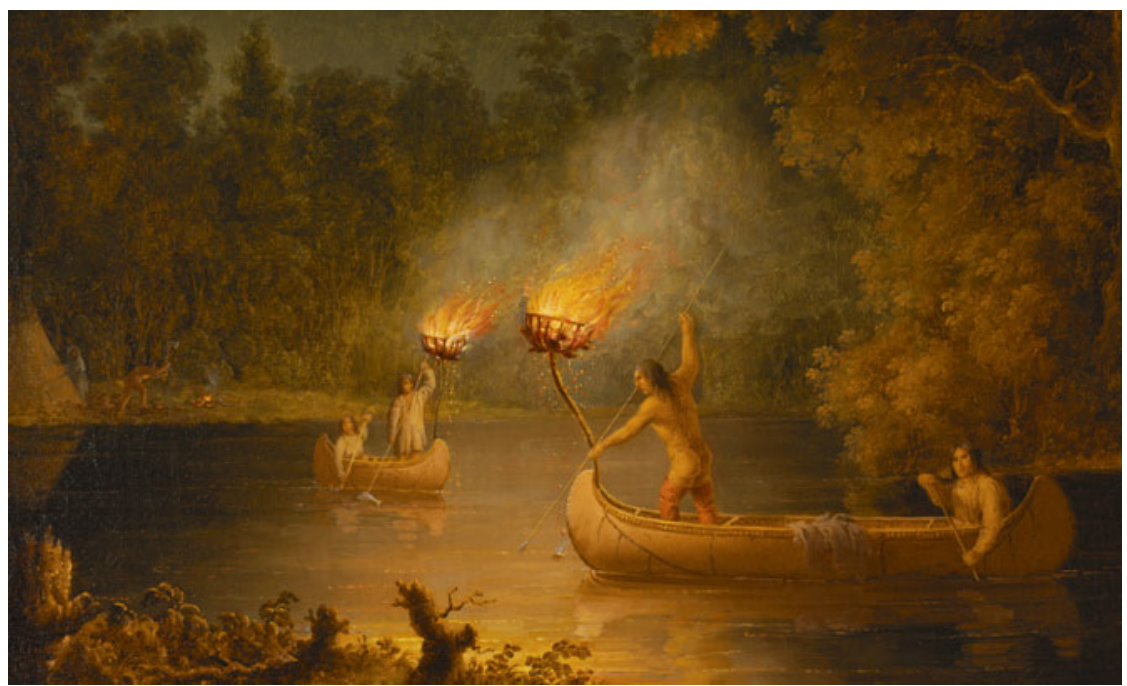

Fig. 2. Paul Kane, 'Fishing by torch light', $1849^{-} 5^{6}$. With permission of the Royal Ontario Museum, Toronto, Ontario. (C) ROM.

Natives employed other fishing methods as well. In 1793, a party of Frenchmen recorded passing a place where Iroquois fishers deployed nets in a river, enabling them to 'take thousands of fish as they ascend from the lake or return, at the two fishing seasons'. ${ }^{15}$ Weirs were also used. Sometimes the entire community was involved. Pomroy Jones, a settler in central New York, described how the Oneidas prepared for their annual fishing feast by

driving a row of stakes across the stream just below the fishing ground, and filling the interstices with brush, so as to entirely prevent the escape of a fish...All being thus made ready, the taking of the fish commenced. The old men, women and children were stationed at the lower obstruction and along the margin of the stream to secure the wounded and dying, while the more effective portion of the party, with spears and sharpened stakes, commenced taking their now-doomed captives. ${ }^{16}$

Native fishers did impose limits on their capture of fish. According to Jones, salmon fishing was permitted only after 'the leaves on the trees had acquired

NY, 1883), p. 180; Christian Schultz, Travels on an inland voyage through the states of New York, Pennsylvania... (New York, NY, 1810), pp. 22-3; Firth, Town of York, p. 217 ; Henry, Emigrant's guide, pp. 326-7; [Anna] Jameson, Sketches in Canada and rambles among the red men (London, $\left.185^{2}\right)$, p. $5^{\mathrm{O}}$; Gourlay, Statistical account, p. 404; Kenneth R. Lister, 'Dip nets and jack lights: Paul Kane's views of fishing the Great Lakes region', Ontario Archaeology, 92 (2012), pp. $13^{-26 .}$

${ }^{15}$ Simon Desjardins and Pierre Pharoux, Castorland journal: an account of the exploration and settlement of northern New York state by French émigrés in the years 1793 to I 797, ed. and trans. John A. Gallucci (Ithaca, NY, 2010), p. 29.

${ }^{16}$ Pomroy Jones, Annals and recollections of Oneida county (n.p., 1851), pp. 872-3. 
the size of a fox's ear'. ${ }^{17}$ While anthropologist Shepard Krech has argued that Natives hunted with abandon so long as the prey were abundant, the Oneidas's abiding by this calendrical restriction was not an easy task. ${ }^{18}$ The springtime was too early for most vegetable foods, and the deer were quite thin. In any case, since the number of Native Americans in central New York in the seventeenth and eighteenth centuries probably did not exceed several thousand, this restraint was sufficient to ensure the continued existence of salmon.

\section{I}

The end of the American Revolution released a wave of Euro-American settlement around Lake Ontario. This was initially most pronounced to the south, as New York moved quickly to dispossess the Iroquois Six Nations, most of whom had supported the British during the war. New England was the principal source of immigrants, since depleted soils and population growth had generated significant pressure to leave. Between 1784 and 1815 , roughly 100,000 people settled on the New York side of the Lake Ontario watershed. Settlement on the Canadian side was perhaps half that; these were also mostly emigrants from the former thirteen colonies who moved there for political or economic reasons.

Many of the writers who described the region's fish during this era did so with an eye towards attracting settlers to the region. A 1798 advertisement for a farm on Yonge Street near York (present-day Toronto) pointed to the property's 'excellent salmon fishery, large enough to support a number of families, which must be conceived a great advantage in this infant country'. ${ }^{19}$ Fish were important, even critical, to frontier immigrants, especially large families. Agriculture would not support them until several months after settlement, and the ability to carry supplies with them was limited. Food shortages in new settlements were both commonplace and life-threatening. Frontier dearths, such as the one that took place when the 1789 wheat harvest failed, were widely reported in the press. Chillingly, in the United States in particular, the news did not spur relief shipments, but instead had the opposite effect: farmers and merchants with grain on hand held on to their stocks all the more tightly in anticipation of higher prices. In British Canada, relief shipments were organized, but often reached their destinations too late to relieve the most significant suffering. ${ }^{20}$ Thus, the appeal of salmon to potential frontier settlers was great: it was a food that would come to them in their new homes under its own

${ }^{17}$ Jones, Annals, p. 873 .

18 Shepard Krech III, The ecological Indian: myth and history (New York, NY, 2000).

19 Quoted in Bogue, Fishing, p. 23.

${ }^{20}$ Alan S. Taylor, 'The hungry year: 1789 on the northern border of revolutionary America', in Alessa Johns, ed., Dreadful visitations: confronting catastrophe in the age of Enlightenment (New York, NY, 1999), pp. 159-61. 
power, it could be captured relatively easily and safely, and it was more reliable than the charity of their fellows.

For settlers, the salmon represented a gift bestowed by God, a down payment on the rewards they would reap for transforming a landscape they understood as 'wild'. As such, they felt entitled to partake of it liberally. Although many settlers came from regions in which salmon populations had declined greatly, the plenitude in their new location-and the spectre of their own hungerobviated any concern about conservation. Writing the pioneer history of his county in the 1840 , Joshua V. H. Clark reported that aged pioneers exhibited 'great glee' when relating their exploits in the early days of settlement, such as when they ran salmon into shoals and killed them with pitchforks, clubs, and stones. As historian Alan Taylor has pointed out, this glee was born of fear: fear of starvation, fear of isolation, and fear of wild animals. ${ }^{21}$

The salmon did indeed become a vital supplement to settlers' diets; the early accounts had not misled. As Pomroy Jones put it, 'the luscious salmon almost compensated for the deprivation [of livestock]'. Fish were eaten fresh when available but also 'salted down for winter's use'. ${ }^{22}$ Repetition, preservation, and lack of seasonings undermined the fish's status as a delicacy, though. As settler John M. Richardson recalled, 'Some may say if they could get salmon they would live highly - Would they like broiled salt salmon, no butter, no lard?' However, if Richardson found the salted salmon tiresome, Jones assured his readers that it nevertheless constituted 'a far more palatable substitute for 'meat victuals', than did the salted pigeons substituted by the pioneers of Whitesboro', a nearby settlement with no fishery. ${ }^{23}$

\section{I I}

In Upper Canada in the late 179os, Irish traveller Isaac Weld echoed van der Kemp when he observed 'that if the fisheries were properly attended to, particularly the salmon fishery, the country would be even more enriched thereby than by the fur trade'. ${ }^{24}$ Appropriately, it was the Natives who were the first fish-trade entrepreneurs. The aboriginal fishery had been primarily organized around subsistence, but not exclusively so. Two Seneca women peddling salmon appear in the earliest description of central Iroquoia, dating from the

21 Alan S. Taylor, 'Wasty ways: stories of American settlement', Environmental History, 3 (1998), p. 295; Joshua V.H. Clark, Onondaga; or reminiscences of earlier or later times (2 vols., Syracuse, NY, 1849), I, p. 207.

${ }^{22}$ Jones, Annals, p. 234. The salt spring at Salina, near Syracuse, was the principal source for the preservative for the entire region. Richard H. Bonnycastle, The Canadas in I 84 I (2 vols., London, 1841 ), I, p. 160.

23 Jones, Annals, p. 234; Hugh M. Smith, 'Report on an investigation of the fisheries of Lake Ontario', Bulletin of the U.S. Fish Commission, 10 (1892), p. 197; Bogue, Fishing, p. 24.

${ }^{24}$ Isaac Weld, Jr, Travels through the states of North America, and the provinces of Upper and Lower Canada (2 vols., London, 1799), II, pp. 86-7. 
mid-163os. ${ }^{25}$ Iroquois and Algonquian fishers purveyed significant quantities of fish to European settlers, freeing the latter to concentrate on the work of clearing the land and building houses. In exchange for fish, settlers offered cash and goods that the Indians desired. Weld noted that Mississauga Ojibwes kept lake towns from Kingston and Niagara 'well supplied with fish and game, the value of which is estimated by bottles of rum and loaves of bread' ${ }^{26}$ As settlers proliferated and traditional game animals grew scarce, fishing became an even more important part of the Native economy. In New York, Jones recalled that

As late as 1800 salmon were so plenty, that from three to four cents per pound was a fair price, and many were bought of the Indians for a pint to a quart of rum per salmon. They sometimes brought them in baskets on their backs, and when extra plenty, the Indian ponies were used as pack-horses, on which the fish were somewhat fantastically, and quite ingeniously, bound with bark, the back and sides of the beast having been previously covered with branches of the large-leafed basswood sapling. ${ }^{27}$

John Grew in 1803 observed that the Natives supplied the tavern where he stayed 'as well as those in the Neighborhood, with Fish, Indian Corn \&c.'. As traditional subsistence regimes were compromised by the arrival of large numbers of Euro-American settlers, Natives increased their fishing activity, both for subsistence and trade. ${ }^{28}$

The elements of indigenous belief systems that restrained the hunt did not prove impossible to overcome. As Krech has noted, Natives' belief that spiritbeings on another plane of existence could regenerate all creatures obscured the ultimate consequences of increasing exploitation of the fishery. Native peoples did not believe they could extinguish a creature that also existed in the spirit domain. The problem, as they saw it, was to explain properly their legitimate need to the tutelary spirit of the salmon - in Iroquois terms, its 'grandfather'. Because production was itself a spiritual process, commodification and spirituality were not mutually exclusive. According to Mississauga Ojibwe minister Peter Jones, 'When the white people began to frequent this place for the purpose of taking the salmon, this munedoo [manitou, spirit] took his departure during a tremendous flood caused by his power, and went down the river

${ }^{25}$ Harmen Meyndertsz Van den Bogaert, A journey into Mohawk and Oneida country, ${\text { I } 634^{-}}^{-}$ I635, ed. and trans. Charles T. Gehring and William A. Starna (Syracuse, NY, 1988), p. 6.

${ }_{26}$ Weld, Travels, pp. $85^{-6}$; Firth, Town of York, p. 215.

27 Jones, Annals, p. 386.

28 John Grew, Journal of a tour from Boston to Niagara Falls and Quebec, I 803 (n.p., n.d.), p. 43; Timothy Collingwood Cheney, Reminiscences of Syracuse (Syracuse, NY, 1857), p. 24; Recht, 'Role of fishing', pp. 453-4. On ecological transformation, see A. S. Taylor, 'The great change begins: settling the forest of central New York', New York History, 76 (1995), pp. 265-9o; on Native cultural adaptations, see Karim M. Tiro, The people of the standing stone: the Oneida nation from the Revolution through the era of removal (Amherst, MA, 2011), and Donald B. Smith, Mississauga portraits: Ojibwe voices from nineteenth-century Canada (Toronto, ON, 2013). 
into Lake Ontario.'29 Jones implied that the salmon could return if it so willed. Whether the manitou had also taken umbrage at the Ojibwes' own intensified commercial fishery went discreetly unstated.

Jones's statement also demonstrates that the Natives did not retain a monopoly on fishing - even though they believed themselves entitled to one. In 1790, Mississauga chiefs had protested to British Indian agent John Butler about colonists encroaching on their Credit River fishing grounds. Butler acknowledged their claim and accordingly issued a warning that settlers cease fishing there. However, the government permitted fishing in any other waterway, and some pursued it aggressively for commercial purposes..$^{\circ}$

On the New York side of the lake, Native fishers were displaced more quickly and emphatically. Good Peter, an Oneida spokesman, recalled in 1792 how the loss of their exclusive rights had come to pass. It had happened rather casually at a meeting with Governor George Clinton about three years earlier. Clinton took a rather perverse pleasure in using the metaphorical speech of Indian diplomacy against the Natives. According to Good Peter, Clinton

asked them whether it might not be right for him to throw in a fish hook, into one stream and another as he should pass by; and what he should do in case large fish should appear about his hook - whether he might not thrust his spear into them? [We] answered - By all means, he might have this privilege: but not make a business of it. $3^{1}$

New York settlers did indeed 'make a business of it', with both spears and seines. In a diary of his 1810 travels in central New York, John Hartshorne Eddy 'observed some men hawling a net' with which they had caught forty-seven salmon. Eddy asserted that 'the liberty which the whites have of hawling the seine in this Lake is a great injustice to the poor Oneida Indians, who own most of the land on its shores, and depend in great measure on its fish for their support'. $3^{2}$

\section{V}

Special legal protections testified to salmon's exalted status and acknowledged that the salmon population was diminishing through human agency. In 1800 ,

${ }^{29}$ Krech, Ecological Indian, p. 171; Åke Hultkrantz, 'Water sprites: the elders of the fish in aboriginal North America', American Indian Quarterly, 7 (1983), pp. 1-22; Smith, Mississauga portraits, pp. $4^{1-2}$, qu. at p. 68. For a modern-day restatement, see Ted Williams, Big medicine from Six Nations (Syracuse, NY, 2007), pp. 119, 166-7.

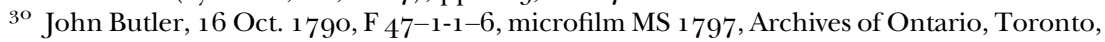
ON; Firth, Town of York, p. liii.

$3^{1}$ 'Good Peter's narrative of several transactions respecting Indian lands', Timothy Pickering papers, Massachusetts Historical Society, Boston, MA, vol. 6o, pp. 127-8.

$3^{2}$ John Hartshorne Eddy diary, 1810 , Newberry Library, Chicago, IL, Ayer MSS 267, p. 98; Jones, Annals, p. 234; 'Journal of Rev. John Taylor's missionary tour through the Mohawk and Black River countries [July 1802]', in E. B. O'Callaghan, ed., Documentary history of the state of New York (4 vols., Albany, NY, 1849-51), III, p. 689. 
New York legislators passed a law that banned all 'obstructions', including seines and weirs, in several important spawning rivers. The law also mandated that all dams have fishways. Failure to comply would make the owner liable to pay a \$200 penalty and result in the dam's removal as a public nuisance. Although subsequent legislation exempted certain watercourses, it was a promising start. In Upper Canada, the 1807 provincial Act for the Preservation of Salmon imposed a general ban on nets and weirs in the populous Home and Newcastle districts. 33

That these laws did not have their desired effect is suggested by the general thrust of subsequent legislation on both sides of the lake, which was to progressively (if incrementally and with occasional reversals) expand protection of the fish. Although some laws weakened protections, most lengthened the closed season, added watercourses, or prohibited specific fishing practices. In 1810 , the Upper Canada law was amended to impose a closed season between 25 October and 1 January and to prohibit the taking of salmon within a hundred yards of a dam or mill. That same year, New York passed a law prohibiting fishing in Wood Creek and Fish Creek in October and November. Indians were exempted - but only if they used less efficient hooks and lines. In April of 1813 , the state outlawed all seines and nets 'across said rivers or creeks below where the salmon are found, so as to prevent the usual course of the salmon from going up the said rivers or creeks'. Hooks, lines, and spears were still permitted, as well as seines and nets that did not completely span the river. In a separate statute, the state barred the use of seines and nets at the mouths of rivers leading into Lake Ontario, although it also permitted dams with fish passages to be erected on Salmon River. 34

Writing his letter to the governor in 1817 , Van der Kemp obviously thought something still more was required, and the 1818 'Act to preserve the salmon fishery in certain waters' may have reflected his influence. In addition to barring nets or other obstructions near the mouth of the Salmon River for the entire period between 1 August and 1 November, it prohibited nets, seines, and weirs in Oneida Lake and its tributaries between ${ }_{15}$ May and 1 December, and limited fishing with spears 'or other implements' to three days a week during those months as well. Violations of the above laws generally

\footnotetext{
33 'An act for the preservation of the salmon in certain rivers' (28 Mar. 180o), New York session laws, ch. 74; 'An act to repeal, so much of 'An act...as relates to the little SalmonRiver' (6 Apr. 1807), New York session laws, ch. 140; 'An act for the preservation of SALMON', Upper Canada statutes, Geo. III, 1807 , ch. 12.

34 "An act to extend the provisions of "An act for the preservation of SALMON", Upper Canada statutes, Geo. III, 1810, ch. 3; 'An act for the preservation of the salmon in Fish Creek and Wood Creek' (23 Mar. 1810), New York session laws, ch. 86; 'An act relative to the fisheries of certain waters' ( 5 Apr. 1813), ch. 62, repeated the proscription against obstructions. 'An act declaring certain waters to be public highways' (2 Apr. 1813), ch. 47; Bogue, Fishing, pp. $176-7$.
} 
carried a fine of $\$ 25$. In Canada, the salmon law was amended in 1823 to prohibit the purchase of salmon from Indians in certain locales. 35

Why did these regulations fail to halt, or probably even slow, the salmon's extirpation? First, they were difficult to enforce unless the law-breaker was caught in the act. Dead fish told few tales. It was not always easy to say how or where a fish had been caught, let alone on what day of the week. Secondly, in both New York and Upper Canada, enforcement was left to people whose only incentive to report a violation was a percentage of the fine collected. The ability of many fishermen to pay that fine was doubtful, and would-be whistleblowers may well have considered good relations with their neighbours to be more valuable than the cash reward. Moreover, in New York, fisheries laws could be - and were - suspended for up to three years by local courts of common pleas. ${ }^{6}$

Another reason why laws on both sides of the border proved ineffective was that they ignored the contribution of land-extensive agriculture to the salmon's decline. North Americans of the time were aware that a wholesale transformation of the landscape had negative implications for aquatic life. 37 An avid angler and amateur naturalist, Governor DeWitt Clinton, observed in 1815 , 'The cultivation of the country has had a prodigious effect in producing this diminution' of fish. He continued,

The cutting down of trees, the drying up of swamps, marshes, the ploughing of land, and the exposure of the soil to the influence of the sun, have lessened these sources of subsistence. The streams and rivers have also been diminished in size, some of them have been entirely dried up. The fountains and springs which furnished cool retreats for the deposite of their spawn, are destroyed. The alluvial deposites have also choked up their ancient places of resort, have discoloured the waters, and rendered them disagreeable and unhealthy, and they have thus been expelled from their former domains. $3^{8}$

Modern science has little to add to Clinton's assessment. But even if the effects of plough agriculture were understood clearly enough, the will to blunt agricultural settlement's impact was limited. While fishermen might be made to change their practices, regulating the ways of farmers to benefit the fish was

\footnotetext{
35 'An act to preserve the salmon fishery in certain waters' (3 Apr. 1818), New York session laws; Bogue, Fishing, p. 178.

$3^{6}$ Bogue, Fishing, p. 176 ; Title XI, sec. ${ }_{15}$, Revised statutes of the state of New York (Albany, NY, 1829), I, pp. $687-9$.

37 Michael Williams, Americans and their forests: a historical geography (Cambridge, 1989), pp. $144^{-5}$.

$3^{8}$ DeWitt Clinton, 'An introductory discourse', Transactions of the Literary and Philosophical Society of New York, 1 (1815), p. 184; Webster, 'Early history', p. 42; idem, 'DeWitt Clinton's “...Fishes of the western waters of the state of New-York" reexamined', Fisheries, 5 (1980), pp. $5^{-12}$.
} 
politically unthinkable. As a means of securing a livelihood, fishing was considered morally suspect, whereas farming was hallowed.39

Chief among the threats to salmon was deforestation. According to the 1845 state census, 25, ooo acres had been 'improved' along the sixteen miles of the Salmon River inhabited by salmon. Since lands adjacent to waterways were the first ones cleared, the waters' exposure to sunlight increased immediately, eliminating hiding places and shade, raising temperature, diminishing oxygen levels, and ultimately lowering volume through evaporation. Deforestation also reduced the insect life that juvenile salmon depended upon for food. Clearing the land of trees also meant that soil dried more quickly and found its way into waterways in greater quantities. $4^{\circ}$

Absence of trees was not the only problem; what the settlers did to those trees also harmed the salmon. Especially at the outset of their farm-building endeavours, cash-poor Euro-American families eagerly transformed troublesome trees into valuable, easily exported commodities like potash and pearlash. Wood ashes supplied important alkali used in the manufacture of gunpowder, glass, medicine, soap, and textiles. Alkaline substances were rare in Europe in the early nineteenth century, so the entire area surrounding Lake Ontario quickly became a key supplier to British industry. The by-products of ash production - most notably lime refuse - were toxic to fish and were disposed of in the water..$^{1}$ According to an 1836 gazetteer, Oswego County, NY, which was prime salmon habitat, had sixteen asheries in operation. There were also twenty-eight tanneries. Tanneries used the bark of hemlock to produce tannin-rich liquids known in the industry as 'ooze' or 'liquor'. Hides were soaked in giant vats to turn them into leather. Lime and sulfuric acid were also used in the process, all of which were released into the waterways. $4^{2}$

39 As a New York canal engineer put the matter with respect to eel fishermen, 'this employment is not of the brilliant national use, which is attached to agriculture', but 'deprive them of this resource, and they will not become husbandmen; they will remain what they were fishermen, or become something worse'. Carol Sheriff, The artificial river: the Erie Canal and the paradox of progress, I $8_{17}{ }_{-1} 862$ (New York, NY, 1996), p. 39; John T. Cumbler, Reasonable use: the people, the environment, and the state: New England, I790-I930 (New York, NY, 2001), pp. 13,15 .

$4^{\circ}$ Sly, 'Effects of land use', 17-20; Hoffman, 'Economic development', pp. 638-40; Bogue, Fishing, pp. 116-18.

$4^{1}$ Taylor, Making salmon, pp. 56-7; Williams, Americans and their forests, pp. 74-5, 139; Taylor, 'The great change', pp. 280-3; idem, 'Wasty ways', p. 304; Harry Miller, 'Potash from wood ashes: frontier technology in Canada and the United States', Technology and Culture, 21 (1980), pp. 196-9; David Stradling, The nature of New York: an environmental history of the Empire State (Ithaca, NY, 2010), p. 33; Edwin C. Guillet, The valley of the Trent (Toronto, ON, $1957)$, p. 31 .

$4^{2}$ Thomas F. Gordon, Gazetteer of the State of New-York (Philadelphia, PA, 1836), p. 620; J. de Fontenelle and F. Malepeyre, The arts of tanning, currying, and leather-dressing (Philadelphia, PA, $\left.185^{2}\right)$, pp. $3^{20-37}$, at p. $3^{21}$. 
And then there were the mills. In $184^{2}$, Scarborough, near York, had $2,75^{\circ}$ inhabitants, one grist mill, and eighteen saw mills. By $185^{\circ}$, the number of mills had risen to twenty-three. Scarborough was nevertheless a laggard compared to other towns in its district, where the number of sawmills alone went from 200 to over 3 oo during that decade. In $18_{3} 6$, Oswego County had 175.43 Still primarily local in nature, the nascent lumber industry used the waterways for transportation to mills and markets. Accumulations of logs affected water flow, and sawmills that cut the lumber for local use generated huge quantities of sawdust, which were disposed of in the water. Sawdust would cover the gravel in which salmon placed their eggs. It also killed many insects they consumed as food. 44

The dams that powered the mills that sawed the timber and ground the farmers' flour constituted one of the most obvious conflicts between the interests of fish and agricultural society. In his 1813 Gazetteer of the state of New York, Horatio Spafford commented that the town of Richland has many 'streams that abound with fish of various kinds, and supply an abundance of millseats'. The Don River at York had been described in similar terms, as 'abounding with Trout, Bass, Salmon \& many other excellent fish \& having a descent sufficient for working all sorts of Mills'.45 Salmon benefited from the high oxygen levels of fast-running streams, but that velocity was precisely what made watercourses desirable for erecting mills and building dams. Good millseats and good fishing were a combination that lured settlers, but they operated at cross-purposes if not managed carefully. Dams were built to harness water flow to power mills for grinding barley, corn, and oats and, of course, to saw wood. However, by slowing and polluting the streams, they rendered them less amenable to the salmon.

Early mills were modest affairs. Initially, many did not even span the waterway, but simply diverted some of the water into a raceway in order to turn a wheel more efficiently. Some dams could be opened and closed for periodic operation. $4^{6}$ Nevertheless, dams posed several problems for migrating salmon.

43 W. H. Smith, Canada: past, present, and future (2 vols., Toronto, ON, $185^{1-2}$ ), II, p. 21 ; J. David Wood, Making Ontario: agricultural colonization and landscape re-creation in Ontario before the railway (Montreal, QC, 200o), pp. 6, 101-6; Gordon, Gazetteer, p. 620.

44 James W. Milner, Report on the fisheries of the Great Lakes (Washington, DC, 1874), p. 19; Jamie Benidickson, The culture of flushing: a social and legal history of sewage (Vancouver, BC, 2007), pp. 39-51; Gilbert Allardyce, "The vexed question of sawdust": river pollution in nineteenth-century New Brunswick', Dalhousie Review, $5^{2}$ (1972), pp. 177-9o; Donald Pisani, 'Fish culture and the dawn of concern over water pollution in the United States', Environmental Review, 8 (1984), p. 121.

45 Firth, Town of York, 18; Horatio Spafford, Gazetteer of the state of New York (New York, NY, 1813 ), p. 282.

$4^{6}$ Philip L. Lord, Mills on the Tsatsawassa: a guide for local historians (Albany, NY, 1983); Louis C. Hunter, History of industrial power in the United States (2 vols., Charlottesville, VA, 1979), I, pp. 1-1 13. 
First and foremost, of course, even though some salmon could leap twelve feet in the air, dams might prevent weaker fish from reaching their spawning grounds. According to an engineer's description of a mill dam on the Humber River in 1797 , fish were unable to surmount the dam and were also getting caught in the mill wheel. Dams also acted as weirs, facilitating the capture of fish. Finally, even if salmon managed to pass over a dam, they could become disoriented by the warm, motionless, and sometimes putrid artificial ponds that dams created (Figure 3). 47

New York's 1800 anti-obstruction statute had mandated apertures to permit fish passage. Upper Canada lacked any fishway statute until 1828, although one had been proposed nine years earlier. However, the laws were apparently not enforced, and even when fishways were present, they were often ineffective because the mechanics of fish jumping were poorly understood. For example, fish required water of a certain depth, but the laws were silent on that point. $4^{8}$ Samuel Strickland observed in the early $185^{\text {os }}$ that around Cobourg there were still many salmon but 'the fishing is not nearly so productive as formerly'. He opined that 'the erection of saw-mills on the creeks, and other causes, have tended materially to injure the fisheries' all along the lake's north shore. Likewise, in 186o, French's Gazetteer observed of Salmon River, 'Before the dams were built upon the river, great numbers of salmon were annually taken.' 49

Compared to New England, legal and physical challenges to dams for damaging fisheries were muted. $5^{\circ}$ In the landmark 1819 New York case People v. Platt, which pertained to the salmon in Saranac River and Lake Champlain, the Supreme Court of Judicature upheld a landowner's unrestricted right to erect a dam in waters not navigable by any but small boats. The court recognized

47 Eleanor Darke, A mill should be build thereon: an early history of the Todmorden mills (Toronto, ON, 1995), p. 22; Charles Sauriol, Remembering the Don: a rare record of earlier times within the Don River valley (Toronto, ON, 1981), pp. 92-3; Elkanah Watson, History of the rise, progress, and existing condition of the western canals (Albany, NY, 1820), p. 34; Sly, 'Effects of land use', pp. 16-17; Hoffman, 'Economic development', pp. 641-2.

$4^{8}$ Journal of the House of Assembly of Upper Canada session, I 825-I826, pp. 94-5; 'An act to provide for the construction of aprons to mill dams', Upper Canada statutes, 9 Geo. IV., c. 4 (1828); Annual report of the commissioners of fish and fisheries of the state of New York (1869), pp. 18-20, 26-7.

49 Major Strickland, Twenty-seven years in Canada West, or, the experience of an early settler, ed. Agnes Strickland (2 vols., London, 1853), I, p. 76; J. H. French, Gazetteer of the state of New York (Syracuse, NY, 1860), p. 520 n. 4 .

$5^{\circ}$ Neil S. Forkey, 'Damning the dam: ecology and community in Ops township, Upper Canada', Canadian Historical Review, 79 (1998), pp. 68-99; Gary Kulik, 'Dams, fish, and farmers: the defense of public rights in eighteenth-century Rhode Island', in Stephen Hahn and Jonathan Prude, eds., The countryside in an age of capitalist transformation (Chapel Hill, NC, 1985), pp. $25^{-5}$; ; David J. Grettler, 'The nature of capitalism: environmental change and conflict over commercial fishing in nineteenth-century Delaware', Environmental History, 6 (2001), pp. 451-73; Richard Judd, Common lands, common people: the origins of conservation in northern New England (Cambridge, MA, 1997), pp. 130-9. 


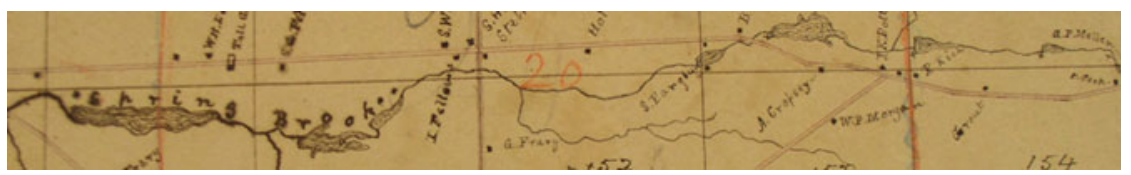

Fig. 3. Seven millponds along Spring Brook. Detail of map of the town of Richland, Oswego County, [1830?], in Hugh White papers. Courtesy New York State Library, Manuscripts and Special Collections, Albany, NY.

no fishing commons to protect. Even if a dam destroyed a salmon population, as Platt's did, it could not be declared a nuisance..$^{5^{1}}$ The court's decision was a harbinger of a larger trend in nineteenth-century United States water law in which rights to fish were suppressed in favour of entrepreneurial uses of water. In Canada, a more conservative judiciary moved more slowly in this direction, but this did not translate into the stronger enforcement of laws mandating fish passages or restricting fishing..$^{2}$

And if mill dams were able to withstand their critics, canal dams were even more impervious. In 1824, a delegation of Oneidas visited the governor of New York to complain about a sixteen-foot dam being erected on the Oswego River. They asked for it to be lowered to twelve feet so that the salmon would be able to pass. Both the governor and surveyor-general suggested the legislature might pay reparations to the Oneidas for their lost fishing, but accommodating the fish was out of the question. As was explained to them, 'the State is building canals and must have water'. The Oneidas were correct in predicting the dam's effect: the tributary waters whose salmon populations were extinguished included Fish Creek, Wood Creek, Oneida Creek, and Oneida Lake.53

\section{I I}

Canals did more than interfere with salmon migration. They advanced greatly the commercialization of fish by bringing many more people to the region

$5^{1}$ People v. Platt, 17 Johns. 195 (NY Sup. Ct. 1819); Robert W. Malsheimer and Donald W. Floyd, 'Fishing rights in nontidal, navigable New York state rivers: a historical and contemporary perspective', Albany Law Review, 62 (1998), p. 163.

$5^{2}$ Morton J. Horwitz, The transformation of American law, I $780-$ I 860 (Cambridge, MA, 1979); Theodore Steinberg, Nature incorporated: industrialization and the waters of New England (New York, NY, 1991); Cumbler, Reasonable use, Benidickson, Culture of flushing, pp. 11-50; idem, 'Private rights and public purposes in the lakes, rivers, and streams of Ontario, $1870^{-}$ 1830', in David H. Flaherty, ed., Essays in the history of Canadian law (Toronto, ON, 1983), pp. 367-9; Bogue, Fishing, p. 177.

53 John Hadcock testimony, 'Report of Abraham Lansing and Anson Wood...to examine claims of the Oneida nation of Indians', 24 Mar. 1874, Documents of the Senate of the state of New York (6 vols., Albany, NY, 1874), Iv, doc. 79, pp. 16-17; Clark, Onondaga, I, pp. 170, 174, 388; M. C. Edmunds, 'Observations in the tributaries of Lake Champlain', Report of the commissioner for 1872 and 1873 , US Department of Fish and Fisheries, part 2 (Washington, DC, 1874), p. 628 . 
and facilitating the shipment of barrels of fish to markets near and far. Work had begun on the Erie Canal in 1817. By November of 1823, Niles' Weekly Register reported 3,5 oo pounds of fresh salmon passing through Utica in a single week. Three years later, the Farmer's Journal reported that in New York City 'about five hundred weight of fresh salmon, from Lake Ontario, was sold...at 25 to 30 cents per pound. They were conveyed to this city via the Erie Canal, packed in ice, and in fine order.' 54 That the latter report appeared in an Upper Canadian newspaper reflected the emerging international market in fish; in addition to supplying the growing city of Toronto, fishermen on the Canadian side of the lake were exporting their catch to the United States via schooner and, later, steamboat.

As the Canal Era unfolded, competition over fish generated conflict. In 1820 , landowner Jonathan Hooker had fisherman Jeremiah Cummings prosecuted for trespass for taking salmon, pike, trout, and eels from the waters adjacent to his property on Salmon River. Cummings argued that he was merely exercising a traditional right to fish common waters, but the court, citing English common law, decided that the public right of fishing ended where tidal action did. As the 1824 edition of Spafford's Gazetteer noted, a lot had been at stake: the salmon fisheries there were 'of no mean consideration as a business likely to increase'.55 The state court's decision steered the benefits of that business away from independent fishermen and toward landowners. The latter responded with alacrity: they bought spears and skiffs and organized themselves into companies to catch and market the fish. According to the recollection of one fisherman, B. E. Ingersoll, 'as much as two miles of shore were operated by some companies'. In 1832 , the fishery provided these landowners with a net annual profit of $\$ 4$,ooo. Another fisherman recalled having 'fifteen hundred fresh Salmon in the fish-house at one time' ${ }^{6}{ }^{6}$

However, the Hooker decision did not end conflict over the fishery. Upstream landowners distrusted their counterparts nearer the river's mouth who might take a disproportionate number of fish, and they sought laws to prevent the raising of 'impassable obstructions'. All the river's landowners despised persons who used nets and seines to catch fish at the river's mouth. The landowners complained of newcomers who rented nets, and described them as 'vagrants' ${ }^{57}$ Conflict also erupted over the use of weirs. Ingersoll recalled that

54 Niles' Weekly Register (Baltimore, MD), 29 Nov. 1823; Farmer's Journal and Welland Canal Intelligencer (St Catharines, ON), 11 Oct. 1826, p. 3. I thank Janet Larkin for bringing this source to my attention.

55 Hookerv. Cummings, J-o 134, New York State Supreme Court of Judicature, Utica Judgment Rolls, box 162, New York State Archives, Albany, NY; Malsheimer and Floyd, 'Fishing rights', pp. 164-6; Horatio Spafford, A gazetteer of the state of New-York (Albany, NY, 1824), p. $3^{87}$.

$5^{6}$ Hooker v. Cummings, 20 Johns. 90 (NY Sup. Ct., 1822); Smith, 'Report', p. 197; Oswego Palladium (Oswego, NY), 27 Feb. 1884 .

57 Report of the select committee on the petition of sundry inhabitants of the town of Richland, 15 Mar. 1833, Documents of the Assembly of the state of New-York (4 vols., Albany, NY, 1833), IV, doc. 242 , p. 3. Ultimately, the state legislature permitted the use of seines and 
rival fishermen often tore out the weirs of their neighbors, and the existence of a weir intact was only secured by vigilance day and night: and even among those who operated weirs they were not very popular, as a great many small fish were sacrificed for which there was no use. After the fish began to grow scarce, the use of weirs was entirely discontinued. $5^{8}$

To protect the fishery, landowners also instituted their own conservation regime. Ingersoll recalled that fishing was limited to alternate nights, although he did not specify how long this remained in effect. The enforcement of local or informal conservation rules protecting a property right in fish appears to have been more robust than of state laws protecting a fishing commons. However, neither proved sufficient to reverse the decline in salmon populations. 59

On the northern shore of the lake, conflict continued to take the form of competition between Native and non-Native fishers. In 1825, the Mississauga Ojibwes sent a protest to the lieutenant governor. 'We have always considered ourselves the owners of this [the Credit] River and fishery', they asserted, and they asked him to reimpose an exclusive fishing zone. To maximize the chances for a favourable official response, the Mississaugas described their white competitors as belonging to an 'inferior class', who did not just destroy their fish, but also their morals, by 'introduc[ing] all manner of evil amongst us'. Accepting a share of responsibility for the conservation of the fish, the Mississaugas proposed to refrain from fishing on Saturdays and Sundays, and to cease commercial fishing activity after the tenth of November. They repeated this request the following year, adding the complaint that 'the white people... scatter the offals of the Fish into the Mouth of the River to prevent the passage of the Salmon up the stream'.6o In March 1829, the parliament of Upper Canada disavowed the behaviour of 'idle and dissolute fishermen' and granted the Mississaugas control of the fishery. This law had an important loophole in that it allowed whites to fish in the river with Mississauga permission, which could be obtained through dubious means. The law also had a sunset provision that caused it to expire in $1834 \cdot{ }^{61}$

nets at the river's mouth, but not in the months of September and October. 'An Act to amend "An act relative to the fishery in the county of Oswego"" (15 Apr. 1833), New York session laws, ch. 155 .

$5^{8}$ Smith, 'Report', p. 197.

59 Ibid.

6o Petition of Mississauga Indians to Peregrine Maitland, 16 Nov. 1825, p. 1035; same to same, 14 Dec. 1826, RG7, Gi4, Correspondence from the Office of the LieutenantGovernor of Upper Canada, p. $1142, \mathrm{H}-1$ 1 77, Library and Archives Canada, Ottawa, ON; Lise C. Hansen, 'Treaty fishing rights and the development of fisheries legislation in Ontario: a primer', Native Studies Review, 7 (1991), p. 3; Indian treaties and surrenders (3 vols., Ottawa, ON, 1905-13), I, pp. 35, 38, 40, 52 ; Smith, Mississauga portraits, pp. $4^{6} 5^{1 .}$

61 Derek G. Smith, ed., Canadian Indians and the law: selected documents, I663-1972 (Toronto, ON, 1975), pp. 32-4; 'An act the better to protect the Mississauga Tribes', Upper Canada statutes, 10 Geo. IV, c. 3 (1829). 
In the 183 os, the harvesting of salmon began to spread beyond the spawning rivers. Seth Green of Rochester recalled the arrival from Scotland of the first pound net sometime after $18_{3} 6$. Green described it as 'a curious contrivance' that was operated under great secrecy. Pound nets were set out in the lake, and took advantage of the fact that fish swam in straight lines to guide them into a central holding area from which they were unlikely to escape. Then in his late teens or early twenties, Green secured a job working the new apparatus, which he eventually replicated and used to launch himself into a wildly successful career as a fish merchant. The nets had to be secured to the bottom of the lake and the pounds emptied, so they required larger, broader boats with shallow draft. This represented another quantum leap in capital investment. Green noted that he 'dressed tons of salmon' and that 'after five years, only a few salmon were left' in the lake. ${ }^{62}$ A decline in salmon was unmistakable, and was most marked in the inshore fisheries along the southern and western parts of the lake. By mid-century, Salmon River was the only remaining spawning area on the New York side of the lake. On the Canadian side, only Wilmot Creek and Grafton remained productive. ${ }^{63}$

Pound nets required a lake bottom soft enough to accommodate stakes, so fish in rockier and deeper waters remained unmolested. Before the end of the 1830 , however, fishermen armed with gill nets took to those waters, increasingly in sailboats. In a petition for official recognition, the fishermen of Wolfe Island, near the lake's eastern end, stated they had 'erected Houses and other Conveniences for the Salmon Fishery on Pigeon Island a barren rock of about Four Acres'. Fishermen also began utilizing larger seines; in addition, nets made by fishermen's wives were over time replaced with ones imported from Scotland and manufactured by machine (Figure 4 ).${ }^{64}$

By the late 185 os, railroads cinched the lake, further facilitating the transportation of the catch to Montreal, New York City, and elsewhere. Canadian and American fishermen were thus incentivized to venture still farther into the lake with larger and larger nets. By this point, the salmon had been reduced to a collateral catch, albeit a welcome one, in the hunt for the more-numerous whitefish and lake herring. The last report of a significant salmon harvest came in 1856 , when the superintendent of fisheries of Upper Canada reported 300,ooo salmon landed at Port Credit, and several thousand 20o-pound barrels elsewhere

62 A. B. McCullough, Commercial fishery of the Canadian Great Lakes (Ottawa, ON, 1989), pp. 27, 35; 'Report of special conferences with the American Fish-Culturists Association', Report of the commissioner for 1872 and 1873 , pp. 768-70.

63 Report of the select committee on the petition of...the town of Richland, p. 2; 'Special conferences', Report of the Commissioner for ${ }_{1} 872$ and ${ }_{1} 873$, part 2, p. 770; R. W. Dunfield, The Atlantic salmon in the history of North America (Ottawa, ON, 1985), p. 145.

64 Barbara Wall LaRocque, Wolfe Island: a legacy in stone (Toronto, ON, 20o9), pp. 127-8; Joan L. Ellsworth, 'The eastern Lake Ontario commercial fishery, 1673-19oo: a cultural heritage, a forgotten staple' (MA thesis, Queen's University, 1983), pp. ${ }^{8} 5^{-9}$; McCullough, Commerical fishery, p. 32 . 

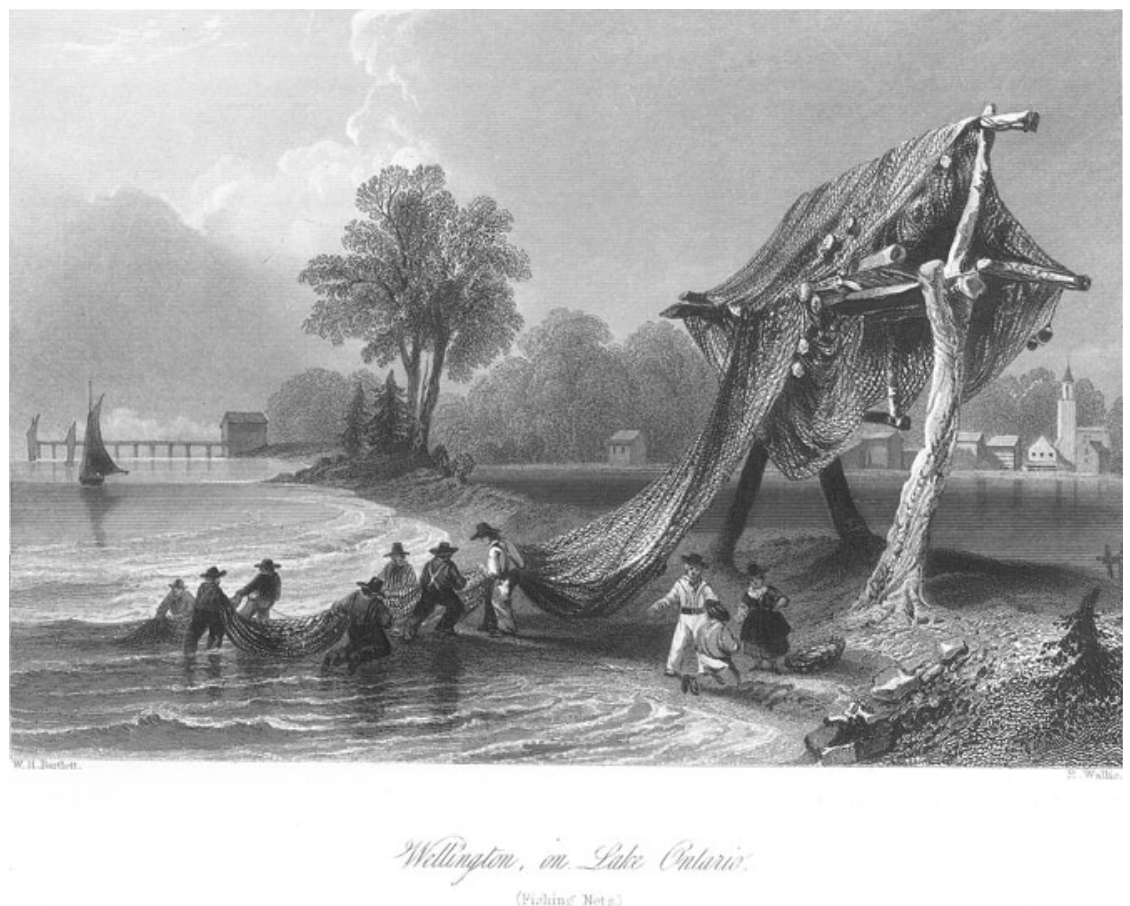

Fig. 4. W. H. Bartlett, Wellington, on Lake Ontario (London, 1842). Courtesy of the author.

in the province. Even then, however, the report's author observed that the salmon population was greatly diminished from earlier decades. He lamented 'the loss - the calamity, I may say, - which we have sustained in the destruction of this noble fish'. Lake Ontario salmon were still advertised for sale in Syracuse as late as $186_{5}$, but their numbers were falling dramatically. ${ }_{5}$

\section{I I I}

Conditions on the spawning rivers and streams worsened from a variety of causes in the second half of the nineteenth century. Some of these represented

65 Ellsworth, 'Commercial fishery', pp. 6o-2, 79, 89-98; Syracuse Herald (Syracuse, NY), 5 July 1885; Richard Rathburn and William Wakeham, Report of the Joint Commission Relative to the Preservation of the Fisheries, Annual Report of the Department of Marine and Fisheries, Canada, Sessional Papers, 31, 8, no. $11 \mathrm{D}$ (1897), p. 39; Milner, Report, pp. 41-2; I. M. Wellington, 'Presqu'Isle', Ontario History, 5 (1904), p. 72; Strickland, Twenty-seven years, I, p. 76; John McCuaig to the commissioner of Crown Lands, Report of the commissioner of Crown Lands of Canada for the year I 857, Appendix 5, p. 81; McCuaig, Annual report of the supertintendent of fisheries of Upper Canada for the year I 859, Appendix 30, p. 81; Standard (Syracuse, NY), 28 Apr. 1865 . 
the extension of earlier transformations. According to a resident of Webster, $\mathrm{NY}$, interviewed in 1894, 'The great trouble is the deposit of silt that comes down from the creeks.' New York fisherman Charles Learned and others noted that 'the country [around Salmon River] is being cleared up so that there is not so much water as formerly in the streams in the latter part of the season'. Wetlands represented critical habitat for juvenile salmon, but were filled to increase the availability of arable land, improve navigation, and diminish the prevalence of disease. Surgeon William Henry Smith's $185^{1}$ Canada: past, present, and future catalogued numerous important marshes on the western side of the lake, many of which would soon be diminished or cease to exist entirely. ${ }^{66}$

Lumber-based mill activity also expanded in this heavily forested region. Around mid-century, wood pulp replaced rags and straw as the principal ingredients in paper. Paper mills were in operation in three counties on the western side of the lake by 1880 , and paper production was even more robust on the American side. By the end of the century, there were eleven mills in Jefferson County, NY, alone. Creating paper from wood pulp involved boiling wood in caustic alkali liquid and hypochlorites. One local observed that the Black River, which had previously supported a salmon run, 'is contaminated by refuse, from paper mills situated not far from its mouth, and the acid used is said to kill pike, bass, and other fish'. ${ }^{6}$ One local attributed the decline in salmon in Salmon River to 'the mills and factories - especially the book-board mill at Pulaski' that 'throw the refuse into the river'. ${ }^{8}$ Proliferating industrial operations - ranging from the manufacture of iron to furniture to carriages to textiles - also demanded larger dams.

Other developments also made the salmon's survival more precarious. Readings taken at Toronto showed an increase in average summer air temperature from $65^{\circ} \mathrm{F}$ at mid-century to $67^{\circ} \mathrm{F}$ by century's end. This increase was doubtless more pronounced at Toronto because of deforestation and urban development, but the entire lake was warming as the Little Ice Age drew to a close. While water temperatures in most streams remained within the tolerable range for vulnerable juveniles, higher temperatures meant less oxygen for the alreadystressed fish. ${ }^{69}$ The remaining salmon also faced a new threat in the form of a

66 S. Smith, 'Report', pp. 197-8, 201; Clark, Onondaga, I, pp. 105-6; Smith, Canada, II, pp. 1, $19,23,37,5^{2}, 202,204,207,213,257,265,444$.

${ }_{7}$ Lyman Horace Weeks, History of paper manufacturing in the United States (New York, NY, 1916), pp. 226, 262-3; William F. Fox, History of the lumber industry in the state of New York (Harrison, NY, 1976), p. 77; Bogue, Fishing, p. 127; Smith, 'Report', p. 198.

68 Goode, 'Salmon', p. 473; Ontario Agricultural Commission, Appendix B, containing returns relating to... the province of Ontario (Toronto, ON, 1881), pp. $187,324,650$.

69 M. K. Thomas, 'Changes in the climate of Ontario', in F. A. Urquhart, ed., Changes in the fauna of Ontario (Toronto, 1957), pp. 63-7; Bror Jonsson and Nina Jonsson, Ecology of Atlantic salmon and brown trout: habitat as a template for life histories (Dortmund, 2011), pp. 138-40; J. Donald Meisner, John L. Goodier, Henry A. Regier, Brian J. Shuter, and W. Jack Christie, 'An assessment of the effects of climate warming on Great Lakes Basin fishes', Journal of 
new fish in the lake: the alewife. The presence of alewives in the watershed was undocumented prior to 1873 , but by 1890 it had become its most numerous fish. Although alewives were preyed upon by many fishes, alewife consumption has been linked to a thiamine deficiency that is devastating to Atlantic salmon fertility in particular. $7^{\circ}$

\section{X}

Commercial fishermen's complaints about dwindling salmon stocks remained muted so long as other commercial species remained viable. ${ }^{71}$ Fishermen understood that remedial legislation would take the form of regulations aimed at their activities but not those of farmers or manufacturers. However, after mid-century, a new, noisy constituency of citizens with a deep interest in fish emerged, and the politics of salmon legislation changed dramatically. For people of leisure, accelerating urbanization and industrialization heightened the romantic appeal of angling. As one essay published in both Canada and the United States put it, angling was an antidote to the city: it took a man 'far enough from the busy haunts of his fellows to get rid of the foul atmosphere too often engendered, morally and physically, by their herding together'..$^{2}$ Sport fishing increased on both sides of the lake as elites discovered the regenerative power of nature.

Great Lakes Research, 13 (1987), pp. 340-52; Smith, Early changes, pp. 13-15; Catherine Carlson, 'The Atlantic salmon in New England prehistory and history: social and environmental implications' (Ph.D. dissertation, University of Massachusetts-Amherst, 1992), p. 220.

$7^{\circ}$ Smith, 'Report', p. 19o; Tarleton H. Bean, 'On the occurrence of the branch alewife in certain lakes of New York', in Fisheries and fishery industries, pp. 588-91; S. H. Smith, 'Species interactions of the alewife in the Great Lakes', Transactions of the American Fisheries Society, 9o (1970), pp. 754-65; idem, Responses of fish communities to early ecologic changes in the Laurentian Great Lakes (Ann Arbor, MI, 1984), pp. 16-19; R. A. Daniels, 'Untested assumptions: the role of canals in the dispersal of sea lamprey, alewife, and other fishes in the eastern United States', Environmental Biology of Fishes, 6o (2001), pp. 315 $5^{-19}$; H. George Ketola, Paul R. Bowser, Gregory A. Wooster, Leslie R. Wedge, and Steven S. Hurst, 'Effects of thiamine on reproduction of Atlantic salmon and a new hypothesis for their extirpation in Lake Ontario', Transactions of the American Fisheries Society, 129 (2000), pp. 610-1 1. Green's description of salmon with empty stomachs has been used to support the alewife thesis for salmon decline, but he was referring to the 183 os - well before the alewife was established around Lake Ontario.

$7^{1}$ For an analogous situation elsewhere in New York, see R. A. Daniels, Robert E. Schmidt, and Karen E. Limburg, 'Hudson River fisheries: vast to dwindling in 4 oo years', in Robert E. Henshaw, ed., Environmental history of the Hudson River: human uses that changed the ecology, ecology that changed human use (Albany, NY, 2011), pp. 32, 37.

$7^{2}$ Quoted in Nancy B. Bouchier and Ken Cruikshank, "Sportsmen and pothunters": environment, conservation, and class in the fishery of Hamilton Harbour, 1858-1914', Sport History Review, 28 (1997), p. 8; Mark Chochla, 'Victorian fly fishers on the Nipigon', Ontario History, 41 (1999), pp. 151-63; John F. Reiger, American sportsmen and the origins of conservation (Corvallis, OR, 2OOO). 
Elite sport-fishermen entered the fisheries debate with great éclat. Reflecting on New York's failure to protect wildlife, influential sportsman, writer, and editor Henry William Herbert in 1866 stated that it was 'impossible to feel anything but contempt for such unutterable blockheadism'.73 Two years later, Thaddeus Norris opined that 'our utter disregard for the bounties of nature... and our inordinate rage for internal improvements, have caused our state governments rather to legislate for the extinction than the protection and continuance of the finer species of migratory fishes'. Norris concluded, 'These are not the natural consequences of civilization and progress...but rather of barbarism and reckless improvidence.'74 By 'barbarism and reckless improvidence', Norris meant commercial and even subsistence fishing, which sportsmen regarded as the wasteful activities of indolent ne'er-do-wells. Elites extolled angling but excoriated ongoing net, seine, and spearfishing as unsporting and unsustainable.75 Sportsmen thus urged legislators and courts to consider public enlightenment and tourism as uses that they should value and protect. In Canada, sportsmen lent critical support to the passage of the 1857 and $185^{8}$ Fisheries Acts. ${ }^{6}$ In New York, in order to get the legislature to pass new laws and enforce existing ones, prominent sportsmen pushed for the creation of a standing fish commission. Two sportsmen, ex-governor and presidential candidate Horatio Seymour and attorney Robert Barnwell Roosevelt (uncle of Theodore), were among the first commissioners in 1868.77 Commercial fishermen retorted that the anglers were, in fact, the wasteful ones, since they took fish for sport and show, rather than for food. But the legislators ignored the fishermen and passed laws further restricting the catch. The fishermen in turn ignored the legislators, flouting their laws. $7^{8}$

With Lake Ontario's Atlantic salmon ebbing into oblivion, the sportsmen confidently heralded a bright, new, pink-orange dawn, a world of salmon abundance. This miracle, they claimed, would be brought about through

73 Henry William Herbert, Frank Forester's fish and fishing (New York, NY, 1866), p. 167.

74 Thaddeus Norris, American fish culture (Philadelphia, PA, 1868), pp. 20-1.

75 Charles Lanman, 'Our finny tribes', American Review, 6 (1847), p. 493; Bouchier and Cruikshank, "Sportsmen and pothunters", pp. 9-11; Reiger, American sportsmen, pp. 11, 17, $47^{-8,} 75^{-6 .}$

${ }^{6}$ R. Peter Gillis, 'Rivers of sawdust: the battle over industrial pollution in Canada, $1865-$ 19o3', Revue d'études canadiennes/Journal of Canadian Studies, 21 (1986), pp. 86-7; Richard S. Lambert, Renewing nature's wealth: a centennial history of the public management of lands, forests, $\mathcal{E}^{\circ}$ wildlife in Ontario, $1763-1867$ ([Toronto, ON], 1967), pp. 113,151 . This work acknowledges the role of sportsmen but reserves primary credit for government functionaries.

77 Reiger, American sportsmen, pp. 77-8; Sir Alan McNab, former prime minister of Canada West, became first president of the Society for the Protection of Game and Fish, a private organization, Bouchier and Cruikshank, "'Sportsmen and pothunters", p. 6.

$7^{8}$ Syracuse Daily Standard (Syracuse, NY), 1 Apr. 1859 ; interview with B. E. Ingersoll, 4 Oct. 1894, pp. [25, 26, 38], Records of the Joint Fisheries Commission Relative to the Preservation of the Fisheries in Waters Contiguous to Canada and the United States, box 16, RG22, National Archives, Washington, DC. 
pisciculture, the science of fish breeding and rearing. 79 In 1857 , New York state senator John Ferndon declared, 'It will be as easy to stock...appropriate streams

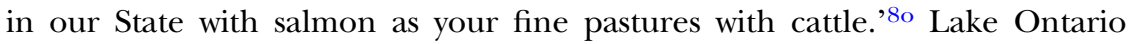
became the epicentre of North American fish breeding. Samuel Wilmot of Newcastle, Upper Canada, was the most prominent pisciculturist of his day. As one salmon stream after another had been extinguished, Wilmot had been moved to save the population that still existed in the creek that bore his family's name. In 1866, after several years of experimentation, he had started a hatchery. His early success in producing hatchlings by the tens of thousands and then actual adult salmon - brought government support to expand his operation, and encouraged others to follow suit. Hatcheries built on Wilmot's model were established in Atlantic Canada and New England. ${ }^{81}$

Wilmot's most notable American counterpart was none other than Seth Green, the Rochester fish baron of pound-net infamy. Green had remade himself in the 1860 os into a fish breeding guru, and won great influence among scientists and sportsmen. With fish commissioner Roosevelt, he coauthored Fish hatching and fish catching in 1879. In the book's introduction, they offered a typically modest assessment of the enterprise of fish hatching: 'success...has swept away fear and hesitation, and experience may now be said to have fully confirmed the highest hopes of the most sanguine'. ${ }^{2}$ These hopes proved illusory. A mere two years later, Wilmot declared, 'I cannot disguise from myself that the time is now gone by forever for the growth of salmon and speckled trout in the frontier streams of Ontario.' 83 His salmon had vanished. Wilmot's success during the 1870 s had probably been amplified by unusually high rainfall. While some wild fish species were successfully propagated using artificial means, pisciculture had many failures, including the Atlantic salmon. ${ }^{8}$

79 William Knight, 'Samuel Wilmot, fish culture, and recreational fisheries in late nineteenth-century Ontario', Scientia Canadiensis, 30 (2007), pp. 75-9o; Judd, Common lands, pp. 146-56; Cumbler, Reasonable use, p. 86; Taylor, Making salmon, pp. 10, 69-98.

8o Genio C. Scott, Fishing in American waters (New York, NY, 1869), p. 203; 'Report of the Committee on Agriculture...concerning salmon fisheries in the state', Documents of the Senate of the state of New-York (4 vols., Albany, NY, 1857), IV, doc. 146, p. 3 .

81 Hugh MacCrimmon, 'The beginning of salmon culture in Canada', Canadian Geographical Journal, 71 (1965), pp. 96-103.

82 Robert Barnwell Roosevelt and Seth Green, Fish hatching and fish catching (Rochester, NY, 1879), p. 3; Sylvia R. Black, 'Seth Green: father of fish culture', Rochester History, 6 (1944), pp. $23-4$.

83 Pisani, 'Fish culture', p. 119 ; David Jenkins, 'Atlantic salmon, endangered species, and the future of environmental policies', Comparative Studies in Society and History, 45 (2003), p. 855; J.R. Dymond, 'Artificial propagation in the management of the Great Lakes fisheries', American Fisheries Society Transactions, 86 (1957), pp. 384-91; Bogue, Fishing, pp. 26-7.

${ }^{8}$ Huntsman, 'Why did Ontario salmon disappear?', p. 95; Neil S. Forkey, 'Maintaining a Great Lakes fishery: the state, science and the case of Ontario's Bay of Quinte, 1870-1920', Ontario History, 87 (1995), pp. 45-64; for a successful, albeit environmentally problematic, 
For the duration of the nineteenth century, people all around Lake Ontario had understood that the salmon population was dwindling as a result of fishing and land use practices and economic development. The salmon had been extinguished as a result of changes that were both wide and deep. Despite a desire for the continued existence of Atlantic salmon in the lake, the economic and social rewards of destroying both the salmon and their habitat proved irresistible. Legislation amounted to half-measures that were generally ignored. With the end of the salmon in sight, Euro-Americans made the same manoeuvre Natives had some decades before. Although they were under far less pressure to harvest fish and enjoyed much more control over their circumstances than the Natives, Euro-Americans understood that successful remedial action would still have been economically and culturally disruptive. A more appealing option was to be delivered from the consequences of their actions through the intervention of beneficent, powerful others possessed of the ability to regenerate the salmon ad infinitum. Indigenous ritualists had failed to produce resurgent runs of wild Atlantic salmon in the first half of the century. The manitou and grandfather spirits had remained unmoved. Now it was the turn of the pisciculturists and their vaunted hatchery boxes. The results, however, were the same.

pisciculture effort, see Anders Halverson, An entirely synthetic fish: how rainbow trout beguiled America and overran the world (New Haven, CT, 2011 ). 